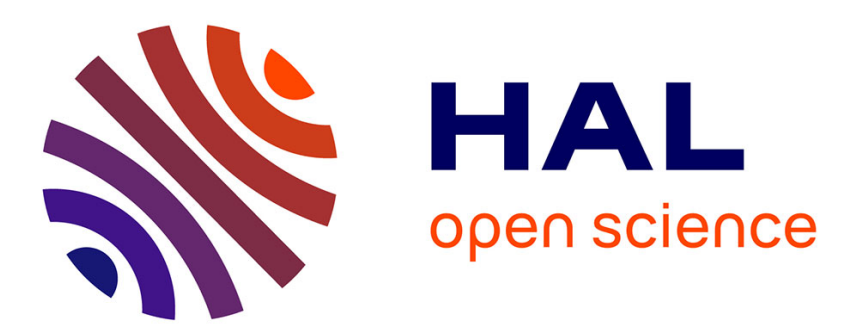

\title{
Temporal stability of soil moisture spatial variability at two scales and its implication for optimal field monitoring
}

\author{
X. Zhou, H. Lin, Q. Zhu
}

\section{- To cite this version:}

X. Zhou, H. Lin, Q. Zhu. Temporal stability of soil moisture spatial variability at two scales and its implication for optimal field monitoring. Hydrology and Earth System Sciences Discussions, 2007, 4 (3), pp.1185-1214. hal-00298835

\section{HAL Id: hal-00298835 \\ https://hal.science/hal-00298835}

Submitted on 30 May 2007

HAL is a multi-disciplinary open access archive for the deposit and dissemination of scientific research documents, whether they are published or not. The documents may come from teaching and research institutions in France or abroad, or from public or private research centers.
L'archive ouverte pluridisciplinaire HAL, est destinée au dépôt et à la diffusion de documents scientifiques de niveau recherche, publiés ou non, émanant des établissements d'enseignement et de recherche français ou étrangers, des laboratoires publics ou privés. 
Hydrol. Earth Syst. Sci. Discuss., 4, 1185-1214, 2007 www.hydrol-earth-syst-sci-discuss.net/4/1185/2007/

(C) Author(s) 2007. This work is licensed under a Creative Commons License.
Hydrology and Earth System Sciences Discussions

Papers published in Hydrology and Earth System Sciences Discussions are under open-access review for the journal Hydrology and Earth System Sciences

\section{Temporal stability of soil moisture spatial variability at two scales and its implication for optimal field monitoring}

X. Zhou, H. Lin, and Q. Zhu

Department of Crop and Soil Sciences, The Pennsylvania State University, University Park, PA 16802, USA

Received: 3 May 2007 - Accepted: 10 May 2007 - Published: 30 May 2007

Correspondence to: X. Zhou (xzz2@psu.edu)

\section{HESSD}

4, 1185-1214, 2007

Temporal stability of soil moisture spatial variability

X. Zhou et al.

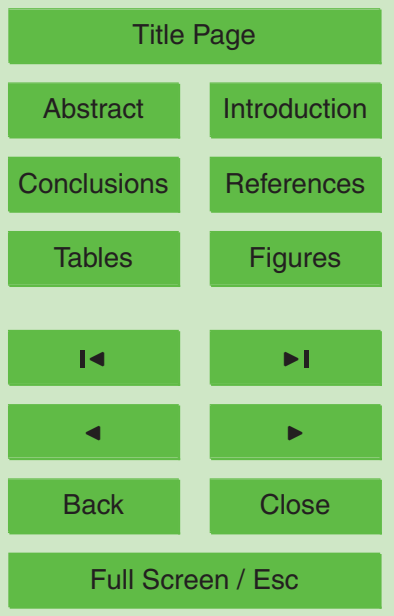

Printer-friendly Version

Interactive Discussion 


\section{Abstract}

Soil moisture spatial distribution is a key component in characterizing and modeling water movement at multiple scales. The temporal stability of soil moisture spatial distribution at multiple depths was investigated at the 7.9-ha Shale Hills Catchment in 5 central Pennsylvania with a year-round monitoring of 77 sites distributed across the catchment. For this catchment with heterogeneous soils and landforms, integration of soils information into the temporal stability assessment provided a more accurate location of representative monitoring sites for capturing mean soil moisture. The temporal stability pattern of soil moisture at the swale scale was similar to that at the catchscale, suggesting that the catchment study in terms of mean soil moisture dynamics. The temporal stability of soil moisture variability in this catchment varied over space and seasons. Temporally stable sites were found in the northwestern and southeastern parts of the catchment, while the areas near the stream and some swale areas had lower temporal stability.

15 The spatial distribution of soil moisture was more stable over time during wet seasons, but less stable during transitional periods (i.e. drying or recharging periods). The temporal stability concept helps the optimal design of field monitoring sites and sampling strategies. On the other hand, the temporally unstable sites provide insights regarding the hydrological processes behind the spatial variability of soil moisture.

\section{Introduction}

Soil moisture spatial distribution is a key component to characterize and model soil water movement and the associated nutrient transport at the catchment scale. Soil moisture often shows a high spatial variation among different landscapes, soil types and vegetations, yet the general pattern of spatial variability in soil moisture is much
HESSD

4, 1185-1214, 2007

Temporal stability of soil moisture spatial variability

X. Zhou et al.

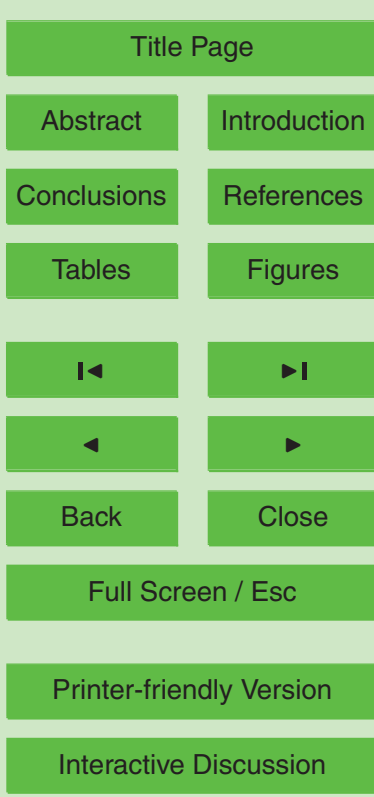

EGU 
al., 2001). For example, the observations of soil moisture content at some locations are consistently higher than, equal to, or lower than the mean soil moisture content over an entire study area. Such persistent association between spatial location and soil moisture over time has been explored within the context of temporal stability con5 cept, initially proposed by Vachaud et al. (1985). Temporal stability suggests that the areal mean soil moisture estimates could be determined from few point measurements of time-stable sites. In precision farm management, an accurate estimation of field mean soil moisture content is the key to guide irrigation activities. Correct definition of antecedent mean soil moisture condition is also critical to simulate and predict the 10 soil moisture dynamics responding to the rainfall inputs in hydrological modeling. The temporal stability of soil water spatial pattern has been investigated to select representative monitoring sites with the aim to optimize or minimize the number of monitoring sites needed in a study area (Grayson and Western, 1998; Cosh et al., 2004; MartinezFernandez and Ceballos, 2005).

15 Soil moisture content is closely related to soil properties and topography, e.g. clay soils often have higher moisture content than sandy soils, and hilltop soils are usually drier than valley floor soils. While the temporal stability of spatial variation in soil moisture status depends on hydrologic processes (Kachanoski and de Jong, 1988; Grayson and Western, 1998), particularly lateral flow, the spatial distributions of soil types and landforms are among the first controls of soil moisture dynamics and landscape hydrologic processes (Chappell and Ternan, 1992; Lin, 2006). The desirable time-stable locations have been found to be related to soil texture and other soil properties, such as soil particle size and soil retention properties (Vachaud et al., 1985; Jacobs et al., 2004; Starr, 2005). Due to the high cost and time-consuming of long-term soil moisture monitoring at the catchment scale, it is rare, if not impossible, that the monitoring sites are uniformly distributed to cover the entire study region. Instead, the design of monitoring sites is usually irregular or located in selected transects (Famiglietti et al., 1998; Gomez-Plaza et al., 2000; Martinez-Fernandez and Ceballos, 2005; Starr, 2005; Lin, 2006). However, the arithmetic mean of all the monitoring sites is generally adopted to
HESSD

$4,1185-1214,2007$

Temporal stability of soil moisture spatial variability

X. Zhou et al.

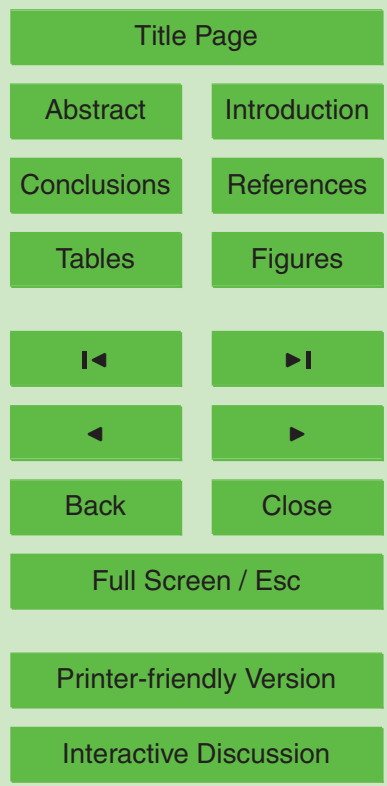

EGU 
represent the mean field soil moisture for monitoring sites selection in terms of temporal stability concept. Consequently, the selected monitoring site(s) may not represent the true mean soil moisture content in an area without grid samplings particularly with heterogeneous soil constitutions and complex topography.

5 In previous applications of temporal stability to identify representative mean soil moisture monitoring sites, most of the studies were based on the soil moisture distribution (Cosh et al., 2004) or water storage (Kachanoski and de Jong, 1988; Grayson and Western, 1998) over certain depths. The mean catchment soil moisture content at multiple depths is important to understand and model the surface and subsurface wa10 ter flow dynamics (Martinez-Fernandez and Ceballos, 2005; Pachepsky et al., 2005). Such mean soil moisture contents at different soil depths, however, may not be represented by the same sets of representative monitoring sites (Tallon and Si, 2003; Lin, 2006), which makes it less feasible for the monitoring site selection based on the temporal stability concept. The representative sites are likely not even adjacent in terms of spatial location (Tallon and $\mathrm{Si}, 2003$ ). An alternative way to locate a set of representative monitoring sites, which can be used to represent the mean soil moisture condition at various depths, would be desirable for monitoring sites selection based on the temporal stability concept.

The objective of this study was to investigate the soil moisture spatial distribution at 20 two spatial scales - the catchment and the swale scales - and to use soil-landscape features to enhance of the use of the temporal stability concept for locating representative soil moisture monitoring sites

\section{Materials and methods}

\subsection{The Shale Hills Catchment}

25 The study area was the 7.9-ha Shale Hills Catchment in central Pennsylvania. Elevation of this V-shaped forested catchment ranges between $256 \mathrm{~m}$ to $310 \mathrm{~m}$ (Fig. 1).

\section{HESSD}

4, 1185-1214, 2007

Temporal stability of soil moisture spatial variability

X. Zhou et al.

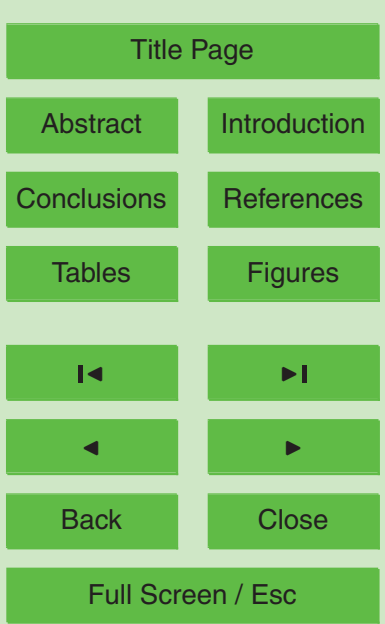

Printer-friendly Version

Interactive Discussion 
The catchment has steep slopes (up to $25 \%-40 \%$ ) and narrow ridges. Four basic landforms has been recognized: 1) south-facing slope with deciduous forest and underbrush, 2) north-facing slope with deciduous forest and thicker underbrush, 3) valley floor or floodplain of a first-order headwater stream with evergreen trees along the 5 western side and deciduous forest on the eastern side, and 4) topographic depression areas (swales) with deciduous forest cover and deeper soils. Seven distinct swales located on the both sides of the valley were mapped using a Trimble Pro XR Global Positioning System (GPS) (Fig. 1). The underlying bedrock in the catchment is composed of Rose Hill shale with more than $200 \mathrm{~m}$ thick (Berg et al., 1980). The soil depth 10 varies from very shallow $(<0.25 \mathrm{~m})$ on the ridge tops and upper side slopes to very deep $(>2-3 \mathrm{~m})$ in the valley floor and swales.

The soils of the Shale Hills Catchment were originated from shale colluvium or residuum, with channery shale fragments $(2-150 \mathrm{~mm})$ throughout most soil profiles. Soils on the hillslopes are characterized by silt loam texture, moderately developed 15 soil structure, and high permeability (Lin et al., 2006). A detailed Order I soil survey was conducted at the catchment using standard grid-transect method (Soil Survey Division Staff, 1993). The soil boundaries were further refined by additional augering and Ground Penetrating Radar investigations (Lin et al., 2006). A total of five soil series, namely Berks (loamy-skeletal, mixed, active, mesic Typic Dystrudepts), Blairton peractive, mesicAquic Fragiudults), Rushtown (loamy-skeletal over fragmental, mixed, mesic Typic Dystrochrepts), and Weikert (loamy-skeletal, mixed, active, mesic lithic Dystrudepts), were identified and mapped, as shown in Fig. 1 (Lin et al., 2006).

Based on the detailed mapping of landforms and soils in the catchment, 77 sites were 25 selected throughout the catchment to monitor soil moisture at multiple depths $(0.1$, $0.2,0.4,0.6,0.8$, and $1 \mathrm{~m}$ or until the maximum soil depth). These 77 sites covered four landform units (hilltop, hillslope, swale, and valley floor) and all soil types in the catchment (Fig. 1). Soil moisture content was measured approximately weekly from 23 September 2004 to 30 October 2005 using the Time Domain Reflectometry (TDR).
HESSD

$4,1185-1214,2007$

Temporal stability of soil moisture spatial variability

X. Zhou et al.

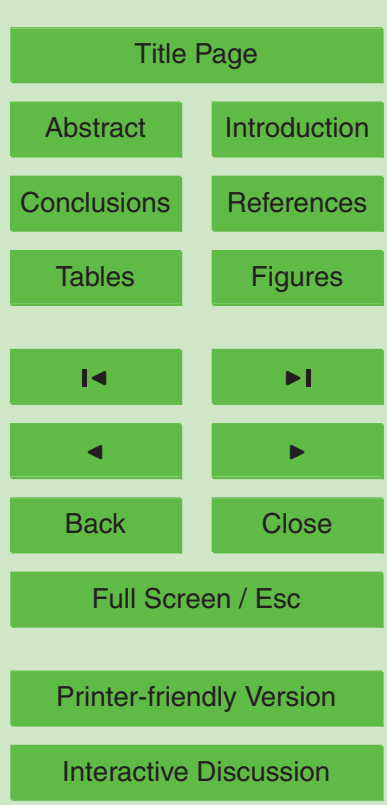

EGU 
No data were collected from mid-December 2004 to mid-February 2005 because of snow cover and frozen soils. We used the TRIME-T3 TDR probe and the TRIMEFM3 mobile meter (IMKO, Germany) to collect volumetric soil moisture content at the desired depths inside a 0.051-m diameter Schedule 40 PVC access tube at each of the 5 monitoring sites. Two sets of readings were taken with the probe rotated $90^{\circ}$ and the average was used to represent the soil moisture content at that depth. Further details of our soil moisture data collection can be found in Lin (2006).

\subsection{Temporal stability analysis}

The relative difference of soil moisture content was used to investigate the spatial variability of soil water status over time (Vachaud et al., 1985). The mean relative difference $\left(\bar{\delta}_{i}\right)$ over time at site $i$ during the monitoring period at a given depth is defined as

$$
\bar{\delta}_{i}=\frac{1}{m} \sum_{j=1}^{m} \frac{\theta_{i j}-\bar{\theta}_{j}}{\bar{\theta}_{j}}
$$

where $\theta_{i j}$ is the measured soil moisture content at that depth for site $i$ on day $j ; m$ is the number of sampling days; $\bar{\theta}_{j}$ is the mean soil moisture content among all the

$$
\bar{\theta}_{j}=\frac{1}{N} \sum_{i=1}^{N} \theta_{i j}
$$

where $N$ is the total number of sampling sites at a specified soil depth in the catchment.

The mean relative difference $\bar{\delta}_{i}$ and its temporal standard deviation $\sigma\left(\delta_{i j}\right)$ have been used to select potential monitoring sites (Grayson and Western, 1998; Mohanty and

Skaggs, 2001). The value of $\bar{\delta}_{i}$ indicate the soil moisture status of a given site as

\section{HESSD}

$4,1185-1214,2007$

Temporal stability of soil moisture spatial variability

X. Zhou et al.

Title Page

Abstract

Introduction

Conclusions

References

Tables

Figures

14

$\rightarrow$

4

Back

Close

Full Screen / Esc

Printer-friendly Version

Interactive Discussion 
compared to the mean soil moisture of the entire study region. A wetter site possesses a positive $\bar{\delta}_{i}$, and a drier site possesses a negative value. The value of $\sigma\left(\delta_{i j}\right)$ is an indicator of temporal stability of soil moisture at a site in comparison to the overall mean of the entire study area. A small standard deviation close to zero indicates a 5 high temporal stability. Sites with $\bar{\delta}_{i} \approx 0$ and small $\sigma\left(\delta_{i j}\right)$ are desirable, if the monitoring purpose is to determine the mean soil water status in a study region, although other sites with small value of $\sigma\left(\delta_{i j}\right)$ can also be used. It should be noted that those sites may not be the optimal sites for other monitoring purposes, e.g. the sites with lower temporal stability may be the hotspots if the underlying hydrologic processes is the focus of a study.

Based on the definition of temporal stability, the soil moisture of a time-stable site at a given day could be deduced if the value of $\bar{\delta}_{i}$ between the sites and the catchment mean soil moisture are known (Grayson and Western, 1998). For two temporal stable sites, $i$ and $k$, soil moisture content at site $k$ on day $j\left(\theta_{k j}\right)$ can be estimated from the 15 site $i$ on the same day $j\left(\theta_{i j}\right)$, which may be regularly monitored:

$\theta_{k j} \approx \frac{\bar{\delta}_{k}+1}{\bar{\delta}_{i}+1} \theta_{i j}$

where $\bar{\delta}_{i}$ and $\bar{\delta}_{k}$ are the mean relative difference for site $i$ and $k$ at a given soil depth, respectively.

The temporal stability of soil moisture spatial variability was evaluated at two scales in this study - the catchment and the swale scales to compare the temporal stability pattern at these two spatial scales. At the catchment scale, the mean soil moisture content on each monitoring day was obtained by averaging the values over all the monitoring sites and used in the relative difference calculation. At the swale scale, only the monitoring sites located within the selected swale were used for temporal stability analysis. The swale \#3 (Fig. 1) was chosen in this study because of its typical V shape
HESSD

$4,1185-1214,2007$

Temporal stability of soil moisture spatial variability

X. Zhou et al.

Title Page

Abstract

Introduction

Conclusions

Tables

References

Figures

14

4

Back

Close

Full Screen / Esc

Printer-friendly Version

Interactive Discussion 
and relatively large number of monitoring sites (a total of 8 sites) within the swale.

To better visualize the spatial pattern of temporal stability at the Shale Hills catchment, the values of $\sigma\left(\delta_{i j}\right)$ of all monitored sites were interpolated using the Inverse Distance Weighted (IDW) method to generate the temporal stability maps of the entire 5 catchment. Other spatial interpolation methods (e.g. ordinary kriging, universal kriging, and co-kriging) were tested but the IDW method provided the smoothest map. Because of the shallow soil depth at the hilltops and hillslopes, the interpolated maps of temporal stability were created only for $10-, 20-$, and $40-\mathrm{cm}$ soil depths, while only the point values were displayed for the $60-$ and $80-\mathrm{cm}$ depths without IDW interpolation due to 10 reduced number of points (Fig. 2).

\section{Results and discussion}

\subsection{Temporal stability distribution across the catchment}

The temporal stability maps at different depths showed that the northwestern and southeastern areas of the catchment had higher temporal stability (i.e. smaller $\sigma\left(\delta_{i j}\right)$ ), ity (i. larger $\sigma\left(\delta_{i j}\right)$ ). The area where the stream starts showed the lowest temporal stability throughout the soil profile within the whole catchment (Fig. 2). The nearby swale \#6 (Fig. 1) has large contribution area and shallow soil depth, which appears to have quick response to rainfall inputs and likely supply source water to the beginning of the stream. Consequently, the area where the stream starts showed high hydrologic dynamics and thus low temporal stability of soil moisture. The intermittent portion of the stream area (along the broken line in Fig. 1) also showed a lower temporal stability because of the higher fluctuation of soil moisture over time. Unlike other hillslope sites, the site 13 at the north-facing hillslope had low temporal stability at 40- and 60$\mathrm{cm}$ depths due to its locally flat topography (Fig. 1). Perched water table has been observed at this site (date not shown). The least time-stability at areas with flat topog-
HESSD

$4,1185-1214,2007$

Temporal stability of soil moisture spatial variability

X. Zhou et al.

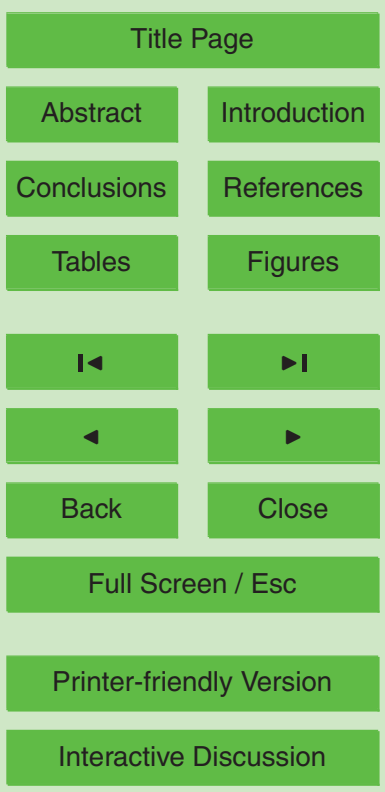

EGU 
raphy was also observed by Mohanty and Skaggs (2001). The other less stable area was located near the stream outlet (Fig. 2). The northwestern and southeastern areas of the catchment had higher temporal stability regardless of the soil depth (Fig. 2).

\subsection{Temporal stability at two spatial scales}

5 The concept of temporal stability and plots of relative difference were used to characterize the spatial variability of soil moisture over time at two spatial scales: the catchment and the swale scales. The geometry of a catchment can be regarded as a self-similar object. A swale, for example, when enlarged could resemble the larger catchment. Therefore, swales may provide a meaningful physical base in the temporal analysis of catchment hydrology.

The pattern of relative differences plots (mean \pm standard deviation) at different soil depths at the swale scale, as exemplified by the swale \#3 in this study, showed similarity to that at the catchment scale (Fig. 3). The temporal stability at each site represented by the standard deviation is almost the same at both scales. Since the temporal stability the mean soil moisture content, it suggests that the average soil water status of the entire catchment could be estimated from the swale scale.

The mean volumetric soil moisture content estimated from 77 sites (the catchment scale) corresponding to each sampling day was plotted against the mean volumetric soil moisture content of the 8 sites within the swale \#3 (the swale scale). A very good linear regression was established for each soil depth (Fig. 4), with $R^{2}$ ranging from 0.96 to 0.99 . Overall, the estimates of mean soil moisture content from the swale were about $90 \%$ to $100 \%$ of the catchment mean, with the best estimate at the $40-\mathrm{cm}$ depth (Fig. 4). The deviation from a 1:1 relationship between the swale and the catchment 25 scales is probably due to the proportions of sites representing various soil types and topographic locations being different at each of the two scales. The Berks soil, for example, has $14.3 \%(11 / 77)$ of sites at the catchment scale, but $50 \%(4 / 8)$ of sites at the swale scale.
HESSD

4, 1185-1214, 2007

Temporal stability of soil moisture spatial variability

X. Zhou et al.

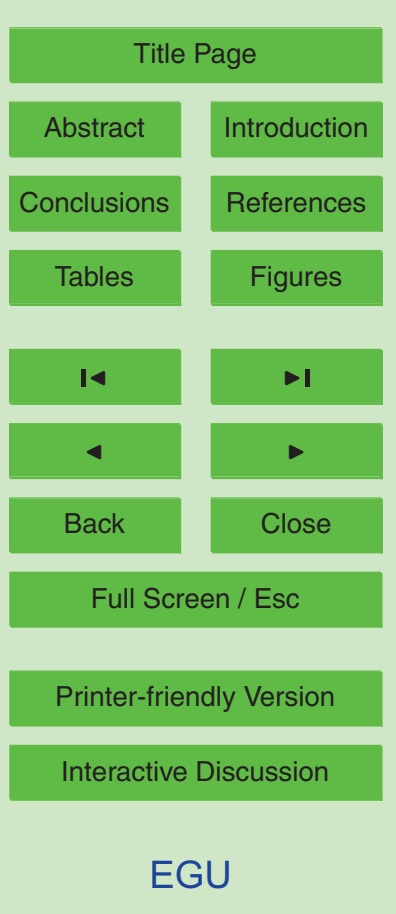


More importantly, such relationship between the swale and catchment mean soil moisture contents persists at each soil depth. As a result, a few sites covering the basic topographic and soil variation within a swale could be used to represent the mean soil moisture condition for the whole catchment at multiple depths (which are often best 5 represented by different sites, as shown in Fig. 5). This may circumvent the challenge of more representative sites needed for multiple depths monitoring.

\subsection{Role of soil distribution in temporal stability analysis}

Soil moisture content varies among different soil types and landforms (Lin, 2006; Lin et al., 2006). The mean soil moisture content of the Ernest soil series at $10 \mathrm{~cm}$ during 10 the entire monitoring period was $0.32 \mathrm{~m}^{3} / \mathrm{m}^{3}$, while the mean soil moisture at the same depth was only $0.19 \mathrm{~m}^{3} / \mathrm{m}^{3}$ for the Weikert soil series. With the detailed soil map, we were able to determine the area of each soil series. Approximately $5.3 \%$ of the catchment was mapped as the Ernest soil series, and $77.9 \%$ as the Weikert. The proportion of monitoring sites representing these two soil series, however, was $10.4 \%$ and $53.2 \%$, respectively. Hence, the selection of average soil moisture monitoring sites using temporal stability concept based on simple arithmetic average may not truly represent the mean soil moisture condition in the study area, which have been widely adopted in other studies (Vachaud, 1985; Grayson and Western, 1998). In a catchment with heterogeneous soil distribution and high spatial variation of landforms, it is necessary to integrate soil and topographic information into the temporal stability assessment. Since the delineation of the soil series in this catchment is closely related to topography (Lin et al., 2006), only the soil spatial variation (as portrayed by soil map) was taken into account in the temporal stability assessment for this study.

The area-weighted mean soil moisture content on each sampling day was obtained 25 by first calculating the arithmetic mean for each soil series, and then area-weighting the mean by the proportion of each soil series' area in the catchment. The representative monitoring sites based on such area-weighted mean were different from the sites using the simple arithmetic mean (Fig. 5). For soil depth at $10-\mathrm{cm}$, for example, the repre-
HESSD

4, 1185-1214, 2007

Temporal stability of soil moisture spatial variability

X. Zhou et al.

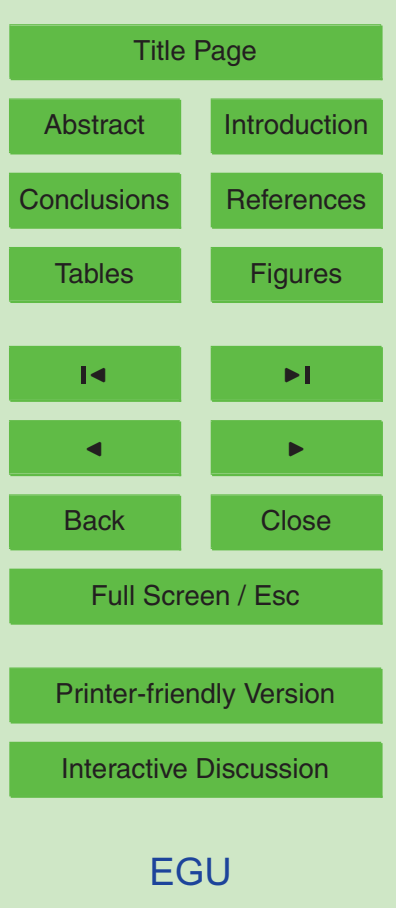


sentative monitoring site with small mean relative difference and high temporal stability was site \#68 when using the classical formula without area-weighted (Eq. 2), but site \#10 was clearly the choice when area-weighted by soil types (Fig. 5). Similarly, sites \#71 and \#B5 was the most representative mean soil moisture site at 20-cm depth for 5 the non-weighted and weighted approach, respectively; and sites \#4 and \#68 at 40-cm depth. Since the soil depth of dominant Weikert series is generally less than $50 \mathrm{~cm}$, the area-weighted mean soil moisture content was not calculated for 60 - and $80-\mathrm{cm}$ depths in this study.

\subsection{Influence of wet-dry transition period on temporal stability}

10 The soil moisture content of a given depth at the Shale Hills Catchment has the following general decreasing trend among different soil series and landforms: Ernest $\geq$ Blairton $>$ Rushtown $>$ Berks $\geq$ Weikert, and Valley floor $>$ Swale $>$ Hillslope $>$ Hilltop (Lin, 2006; Lin et al., 2006). This is illustrated in Fig. 6. The changes of soil moisture over depths were a function of time and soil types, and hence did not show a clear 5 trend (Lin, 2006). As shown in Fig. 6, soil moisture content at $80-\mathrm{cm}$ generally was greater than that at $20-\mathrm{cm}$ depth, but the site \#57 had the opposite trend.

The soil moisture content and relative difference of the sites within the swale \#3 were plotted over the entire monitoring period (Fig. 6). During this period, soils were wet during the winter and early spring, then dried down staring from April, and wetted 20 up again in September. The spatial variation of soil moisture during the wet periods was higher than dry periods (Fig. 6), probably due to lateral redistribution (Lin, 2006).

During the fall and winter seasons, there was little variation of relative difference of soil moisture over time, indicating a high persistence of soil moisture spatial distribution. In this period, soils maintained a wet condition and soil moisture content showed little

change over time, even though the topographic redistribution of soil moisture might still exist. During soil moisture transition periods (i.e. dry down or recharge), the temporal stability was low (Fig. 6). This disruption of temporal stability of soil moisture spatial pattern during recharge periods may be caused by some hydrological processes, par-

\section{HESSD}

4, 1185-1214, 2007

Temporal stability of soil moisture spatial variability

X. Zhou et al.

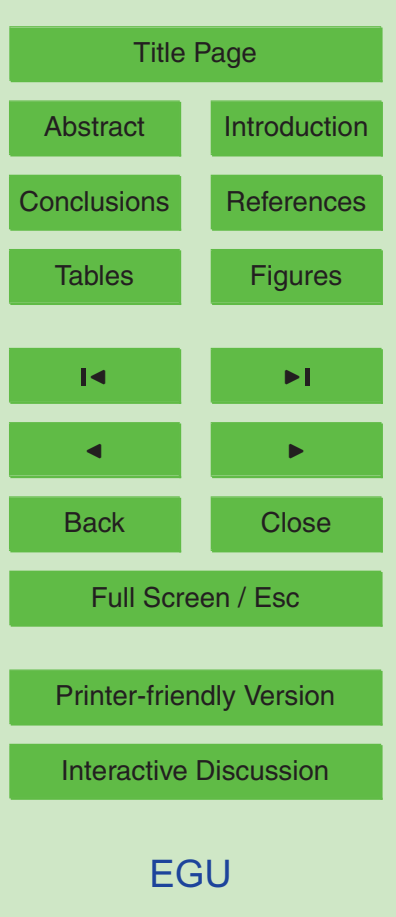


ticularly lateral redistribution of soil moisture (Martinez-Fernandez and Ceballos, 2003; Lin, 2006). Kachanoski and de Jong (1988) examined the temporal persistence of soil water storage for drying and recharge events, and concluded that spatial variability in soil water was induced during recharge but not drying. In our study, however, the tem5 poral stability was low during both dry down and recharge periods (Fig. 6). During the drying periods, the process of uneven evapotranspiration and root water uptake may be the major controls on the soil moisture spatial distribution, even though little lateral redistribution might be involved. This was particularly the case at near-surface soil layers (Fig. 6). Such dynamic process also contributes to the overall variability of spatial distribution of soil moisture over time.

The temporal stability not only changed over seasons or overall moisture status of the study area, but also exhibited difference among the sites. The wetter sites tended to have higher variability than the drier sites. As shown in Fig. 6, site \#15 and \#50 had higher moisture content but less stable than the other sites within the swale \#3, even during winter season. These two sites were located at or near the valley floor, and hence had higher clay content and water-holding capacity. Mohanty and Skaggs (2001) found that fields with silt loam soils had poor temporal stability than those containing sandy loam soils. Furthermore, our results showed that the spatial distribution of soil moisture were more stable at $80-\mathrm{cm}$ depth than at 20-cm depth (Fig. 6).

Among the 77 monitoring sites, stable and unstable sites displayed different temporal stability patterns. For time-stable sites, site \#68 for example, the relative difference is not sensitive to the soil moisture content and the variation is small (Fig. 7). For timeunstable sites, the variation of relative difference is high and shows some trend with soil moisture content. For instance, the relative difference showed a positive linear relationship with the soil moisture content at site \#27 (Fig. 7). This often occurs for the sites on the valley floor.

HESSD

4, 1185-1214, 2007

Temporal stability of soil moisture spatial variability

X. Zhou et al.

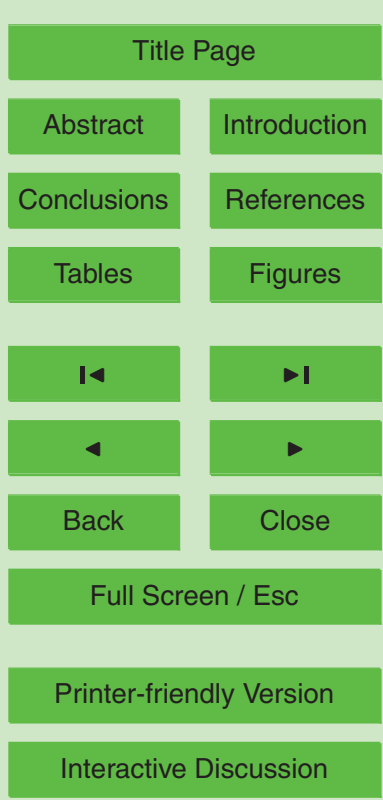

EGU 
HESSD

In the application of temporal stability concept, the time-stable sites have been the focus of many past studies while the less-stable sites were often ignored (Vachaud et al., 1985; Kachanoski and de Jong, 1988; Grayson and Western, 1998). Those time5 stable sites provide potential monitoring locations to represent mean soil moisture for the entire area of interest. In many situations, however, we monitor soil moisture at various locations and depths to understand and model water flow dynamics and flow pathways at the hillslope or catchment scales, rather than the mean catchment soil moisture condition. With this in mind, those sites with low temporal stability may be more of interest than the stable sites.

Soil moisture content of a time-stable site can be estimated from another stable site using Eq. (3). For example, soil moisture contents at site \#33 were estimated from the measurements at site \#68, and plotted against the measured values at 10-, 20-, and 40-cm depths (Fig. 8). The estimated values match the measured values quite well 15 for site \#33 (Fig. 8) and many other sites in the catchment with high temporal stability (Fig. 2). This suggests that we might not need to monitor all the time-stable sites since their soil moisture could be derived from other time-stable sites with accepted accuracy. In our study catchment, most of the stable sites are located at the shallow Weikert and Berks soils (Figs. 1 and 2). Although these two soil types occupy more than $80 \%$ of the area at this catchment, only a small number of sites may be sufficient to capture representative soil moisture in these two soils. The reduction of total monitoring sites without significant loss of information would benefit the long-term field monitoring at larger scales, which often requires a large number of monitoring sites throughout the region that are costly and challenging to remain (Cosh et al., 2004).

25 On the other hand, the soil moisture contents at the sites with low temporal stability can not be accurately estimated from the stable sites, as illustrated for site \#38 (Fig. 9). Those temporally unstable sites may provide more insights on the hydrologic processes behind the spatial variability of soil moisture. For example, lateral flow and redistribution
4, 1185-1214, 2007

Temporal stability of soil moisture spatial variability

X. Zhou et al.

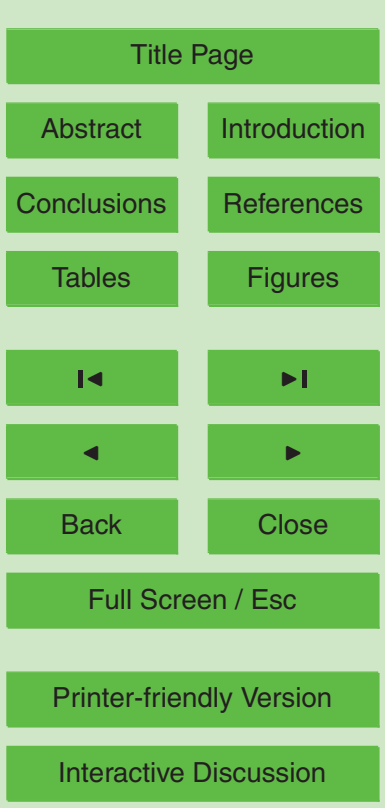

EGU 
is believed to be a major process responsible for the temporal instability of soil moisture spatial pattern at the catchment scale (Kachanoski and de Jong, 1988; Grayson and Western, 1998; Lin, 2006).

The temporal stability of soil moisture may also be used to guide the data collection 5 schedule. Our results showed that the pattern of soil moisture spatial distribution varied over seasons. Temporal stability was relative high during the fall and winter seasons in this catchment. This would be useful for guiding our field sampling strategies. During wet seasons, we may not need to do data collection as frequently as during the dry seasons if monitoring field mean soil moisture dynamics is the main purpose.

\section{Summary and conclusion}

The temporal stability distribution maps at different soil depths revealed that the Shale Hills catchment has more temporally stable sites in the northwestern and southeastern parts of the catchment where shallow Weikert soil dominants, while the areas near the stream and some swale areas have lower temporal stability. Areas in valley floor 15 showed low temporal stability because of the fluctuation of water table, particularly in areas with the intermittent portion of the stream. The temporal stability of the monitoring sites also varied over seasons. The spatial distribution of soil moisture was rather persistent over time during wet seasons, but less persistent during transitional periods, including drying and recharging periods.

The spatial pattern of soil moisture distribution at multiple depths at the Shale Hills showed that the temporal stability of soil moisture spatial pattern at the swale scale was quite similar to that at the catchment scale, suggesting that the swales may be viewed as a miniature of the whole catchment in terms of mean soil moisture dynamics. Excellent linear relationships were established between the swale and the catchment scale mean soil moisture contents.

For a catchment with heterogeneous soils and landforms, integration of soils information into the temporal stability assessment provided a more accurate location of
HESSD

4, 1185-1214, 2007

Temporal stability of soil moisture spatial variability

X. Zhou et al.

Title Page

Abstract

Introduction

Conclusions

Tables

References

Figures

14

4

Back

Close

Full Screen / Esc

Printer-friendly Version

Interactive Discussion 
representative monitoring sites for capturing mean soil moisture of the whole catchment. Area-weighted mean soil moisture of each soil series can be used to obtain the catchment mean soil moisture content of each sampling day rather than the classical arithmetic mean. We have identified representative monitoring sites for catchment-wide 5 mean soil moisture using this approach.

The behavior of temporally unstable sites have often been overlooked in temporal stability analysis in many previous studies, giving the focus on capturing mean soil moisture of a study area. However, temporally unstable sites provide important insights regarding hydrological processes behind the spatial variability of soil moisture, 10 e.g. subsurface lateral flow, evaportranspiration, and perched water table dynamics. Appropriate use of temporal stability concept can benefit optimal design for field monitoring, but must be used with a clear purpose in mind. For example, soil moisture of time-stable sites could be estimated from other stable sites, and thus can reduce the number of monitoring sites needed in a large area.

\section{References}

Berg, T. M., Geyer, A. R., Edmunds, W. E., et al.: Geological map of Pennsylvania. Pennsylvania Geological Survey, 4th ser., Map 1. Harrisburg, PA, 1980.

Chappell, N. A. and Ternan, J. L.: Flow path dimensionality and hydrological modeling, Hydrol. Proc., 6, 327-345, 1992.

20 Cosh, M. H., Jackson, T. J., Bindlish, R., and Prueger, J. H.: Watershed scale temporal and spatial stability of soil moisture and its role in validating satellite estimates, Rem. Sens. Env., 92, 427-435, 2004.

Famiglietti, J. S., Rudnicki, J. W., and Rodell, M.: Variability in surface moisture content along a hillslope transect: Rattlesnake Hill, Texas, J. Hydrol., 210, 259-281, 1998.

25 Gomez-Plaza, A., Alvarez-Rogel, J., Albaladejo, J., and Castillo, V. M.: Spatial patterns and temporal stability of soil moisture across a range of scales in a semi-arid environment, $\mathrm{Hy}-$ drol. Proc., 14, 1261-1277, 2000.

Goovaerts, P. and Chiang, C. N.: Temporal persistence of spatial patterns for mineralizable

\section{HESSD}

$4,1185-1214,2007$

Temporal stability of soil moisture spatial variability

X. Zhou et al.

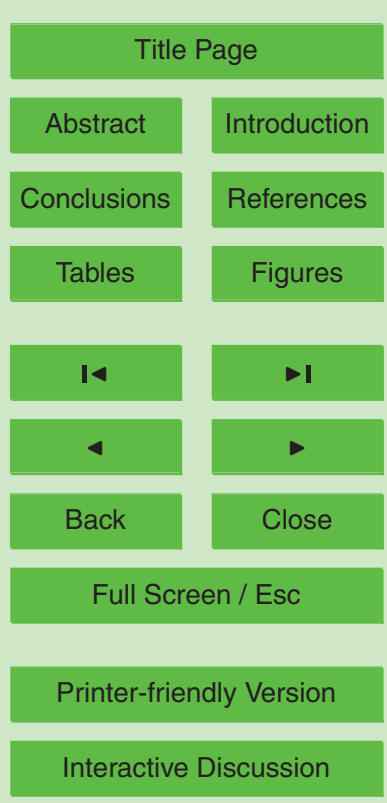

EGU 
nitrogen and selected soil properties, Soil Science Society of American Journal, 57, 372381, 1993.

Grayson, R. B. and Western, A. W.: Towards areal estimation of soil water content from point measurements: time and space stability of mean response, J. Hydrol., 207, 68-82, 1998.

5 Jacobs, J. M., Mohanty, B. P., Hsu, E. C., and Miller, D.: SMEX02: Field scale variability, time stability and similarity of soil moisture, Rem. Sens. Env., 92, 436-446, 2004.

Kachanoshi, R. G. and de Jong, E.: Scale dependence and the temporal persistence of spatial patterns of soil water storage, Water Resour. Res., 24, 85-91, 1988.

Lin, H., Kogelmann, W., Walker, C., and Bruns, M. A.: Soil moisture patterns in a forested catchment: A hydropedological perspective, Geoderma, 131, 345-368, 2006.

Lin, H.: Temporal stability of soil moisture spatial pattern and subsurface preferential flow pathways in the Shale Hills catchment, Vadose Zone Journal, 5, 317-340, 2006.

Mohanty, B. P. and Skaggs, T. H.: Spatio-temporal evolution and time-stable characteristics of soil moisture within remote sensing footprints with varying soil, slope, and vegetation, Adv.

15 Wat. Resour., 24, 1051-1067, 2001.

Martinez-Fernandez, J. and Ceballos, A.: Mean soil moisture estimation using temporal stability analysis, J. Hydrol., 312, 28-38, 2005.

Pachepsky, Y. A., Guber, A. K., and Jacques, D.: Temporal persistence in vertical distributions of soil moisture contents, Soil Science Society of American Journal, 69, 347-352, 2005.

Pires da Silva, A., Nadler, A., and Kay, B. D.: Factors contributing to temporal stability in spatial patterns of water content in the tillage zone, Soil Tillage Research, 58, 207-218, 2001.

Starr, G. C.: Assessing temporal stability and spatial variability of soil water patterns with implications for precision water management, Agricultural Water Management, 72, 223-243, 2005.

Tallon, L. K. and Si, B. C.: Representative soil water benchmarking for environmental monitoring, Environmental Informatics Archives, 1, 581-590, 2003.

Van Pelt, R. S. and Wierenga, P. J.: Temporal stability of spatial measured soil matric potential probability density function, Soil Science Society of American Journal, 65, 668-677, 2001.

Vachaud, G., Passerat de Silans, A., Balabanis, P., and Vauclin, M.: Temporal stability of spa30 tially measured soil water probability density function, Soil Science Society of American Journal, 49, 822-828, 1985.

\section{HESSD}

4, 1185-1214, 2007

Temporal stability of soil moisture spatial variability

X. Zhou et al.

Title Page

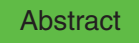

Introduction

Conclusions

Tables

References

Figures

14

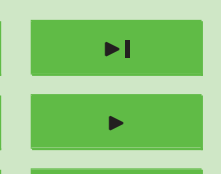

Close

Full Screen / Esc

Printer-friendly Version

Interactive Discussion 


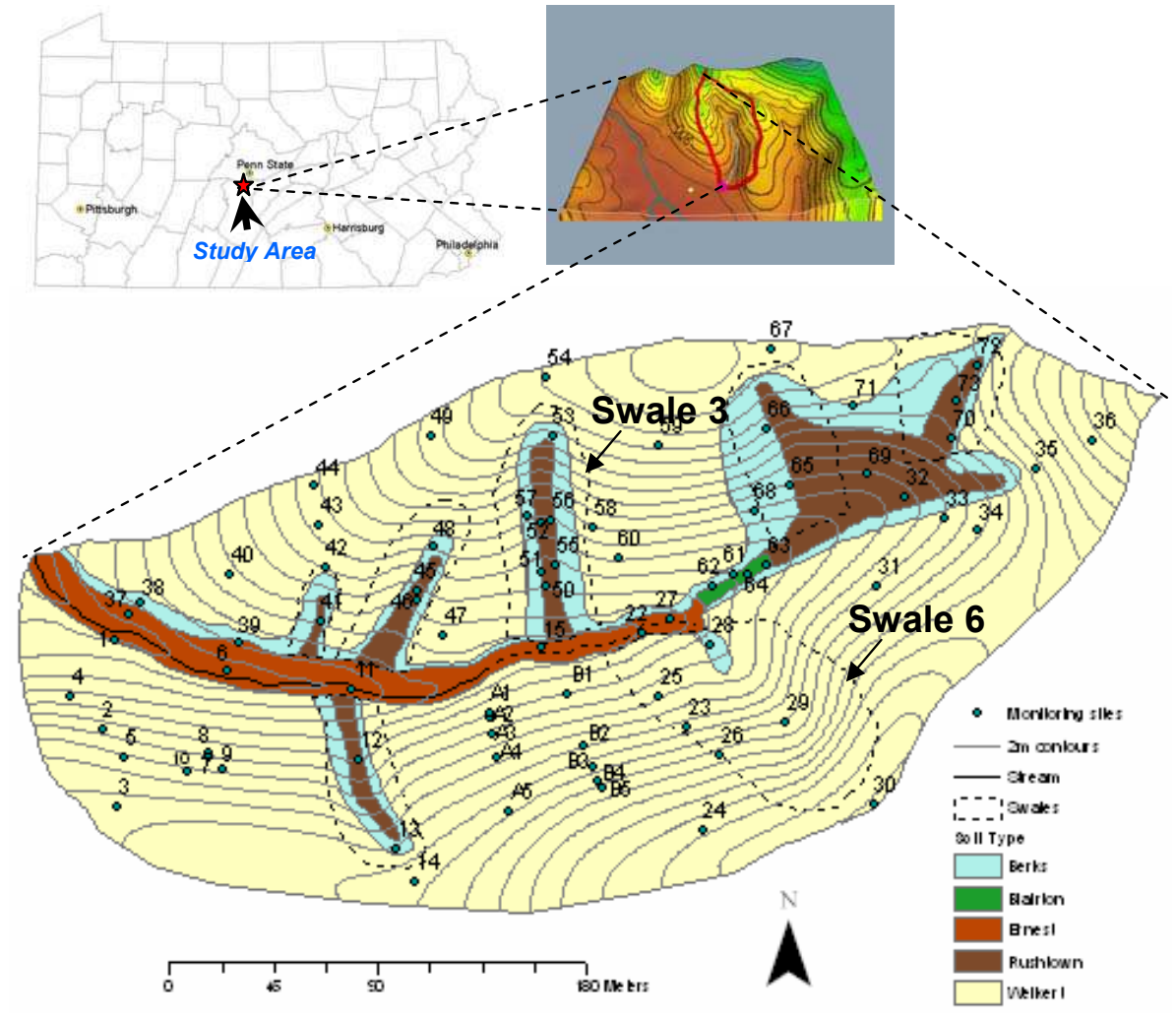

Fig. 1. The study catchment in central Pennsylvania and the distribution of soil types, swales, and soil moisture monitoring sites.

\section{HESSD}

$4,1185-1214,2007$

Temporal stability of soil moisture spatial variability

X. Zhou et al.

Title Page

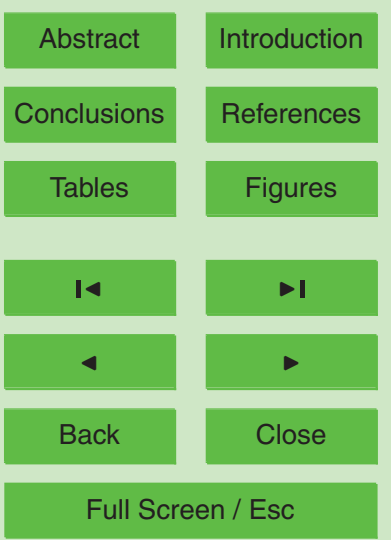

Printer-friendly Version

Interactive Discussion 


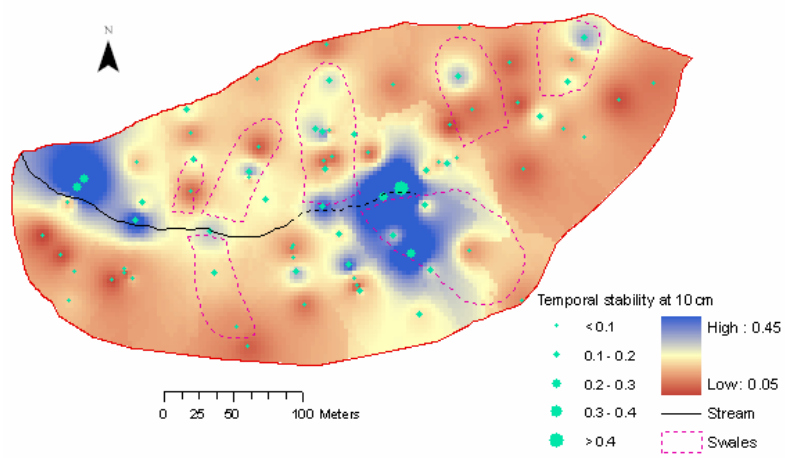

(b) $20 \mathrm{~cm}$ soil depth

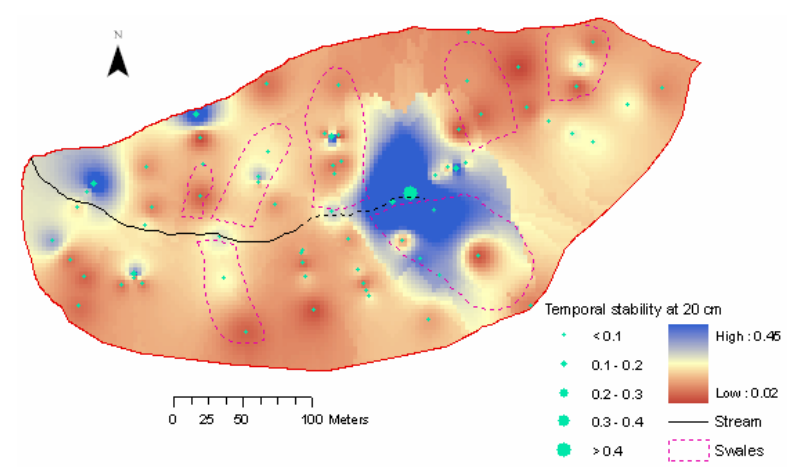

Fig. 2. Temporal stability maps of soil moisture content (i.e. distribution of $\sigma\left(\delta_{i j}\right)$ values) at (a) 10-, (b) 20-, (c) 40-, (d) 60-, and (e) 80-cm depths for the monitoring duration from 23 September 2004 to 24 October 2005. The maps at 10-, 20-, and 40-cm depths were interpolated using the inverse distance weighted method. The dash line represents the intermittent portion of the stream.
4, 1185-1214, 2007

\section{Temporal stability of} soil moisture spatial variability

X. Zhou et al.

Title Page

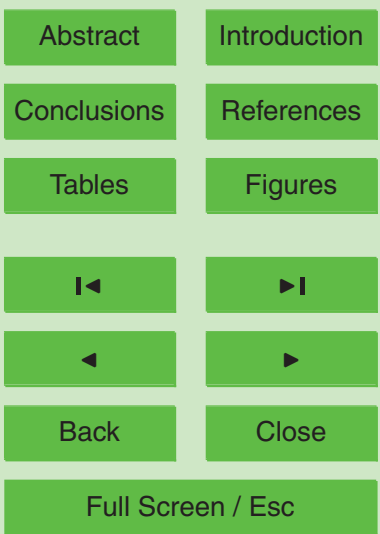

Printer-friendly Version

Interactive Discussion 
(c) $40 \mathrm{~cm}$ soil depth

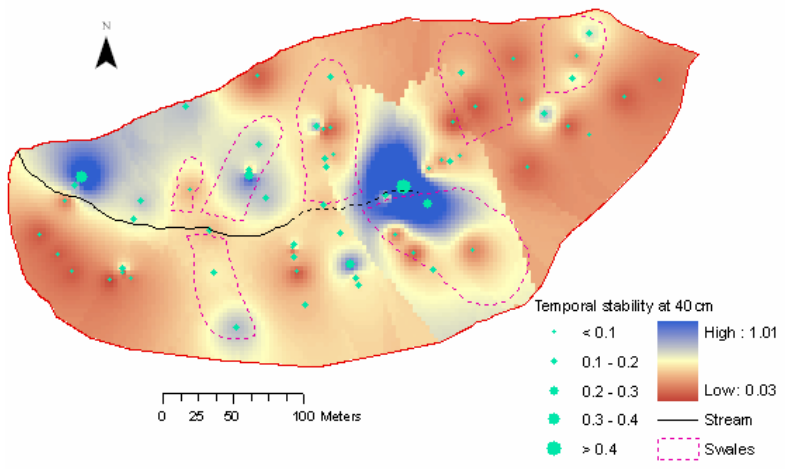

(d) $60 \mathrm{~cm}$ soil depth

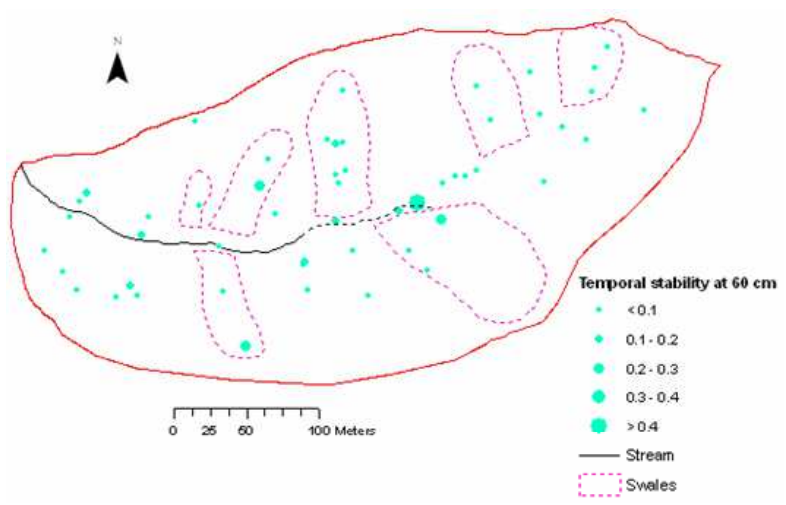

HESSD

4, 1185-1214, 2007

\section{Temporal stability of} soil moisture spatial variability

X. Zhou et al.

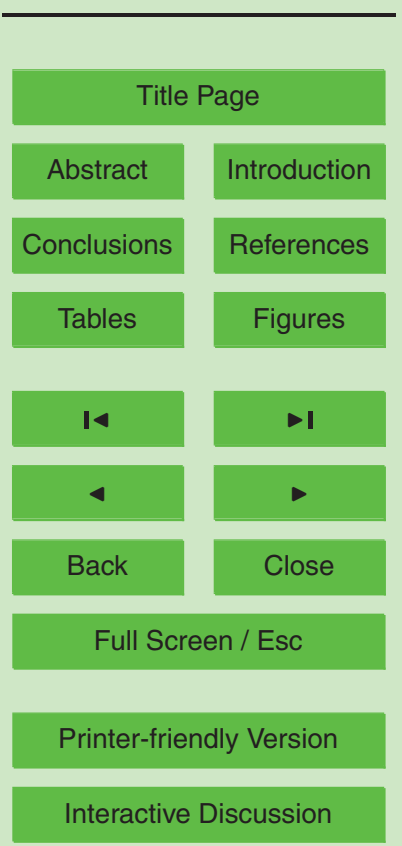

EGU 


\section{HESSD}

4, 1185-1214, 2007

\section{Temporal stability of} soil moisture spatial variability

(e) $80 \mathrm{~cm}$ soil depth

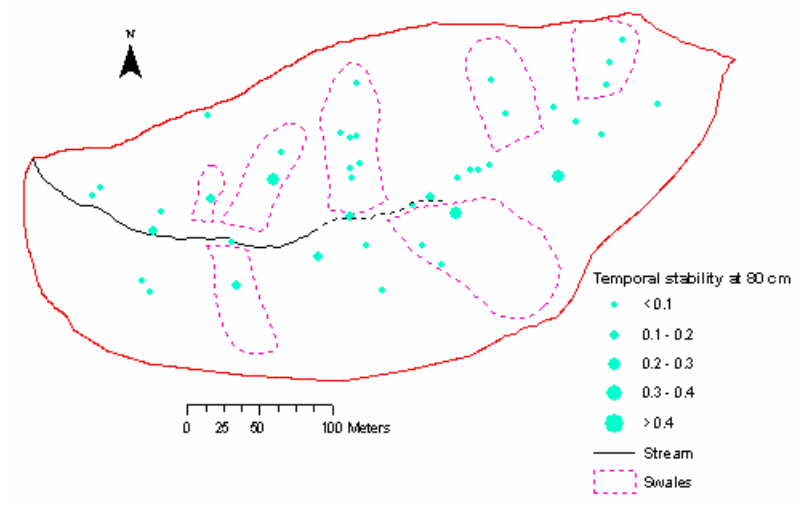

X. Zhou et al.

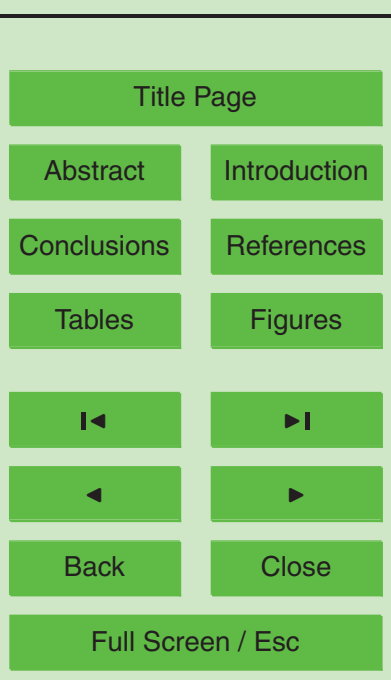

Printer-friendly Version

Interactive Discussion 


\section{HESSD}

4, 1185-1214, 2007

Temporal stability of soil moisture spatial variability

X. Zhou et al.

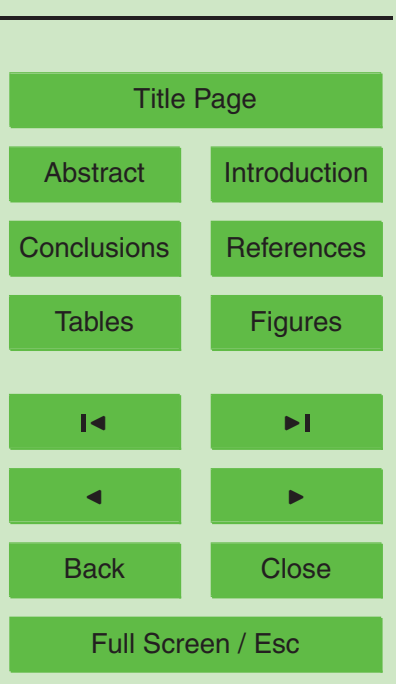

Printer-friendly Version

Interactive Discussion 


\section{HESSD}

4, 1185-1214, 2007

\section{Temporal stability of} soil moisture spatial variability

X. Zhou et al.

\section{Title Page}

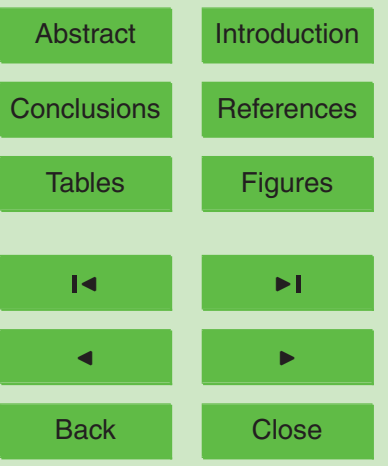

\section{Full Screen / Esc}

Printer-friendly Version

Fig. 4. Mean volumetric soil moisture content at various depths (20-, 40-. 60-. and 80- cm) in the swale \#3 versus the entire catchment.

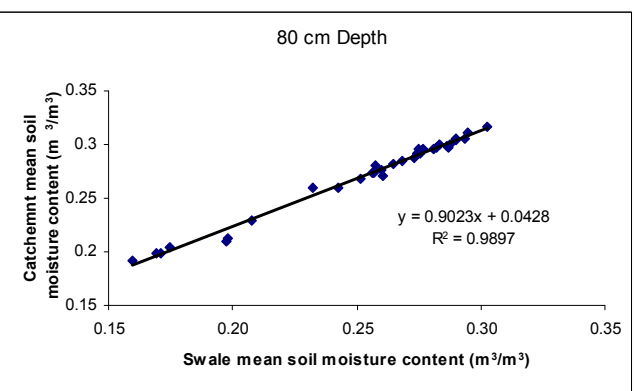

Interactive Discussion 
(a) Without area-weighted (by soil type)
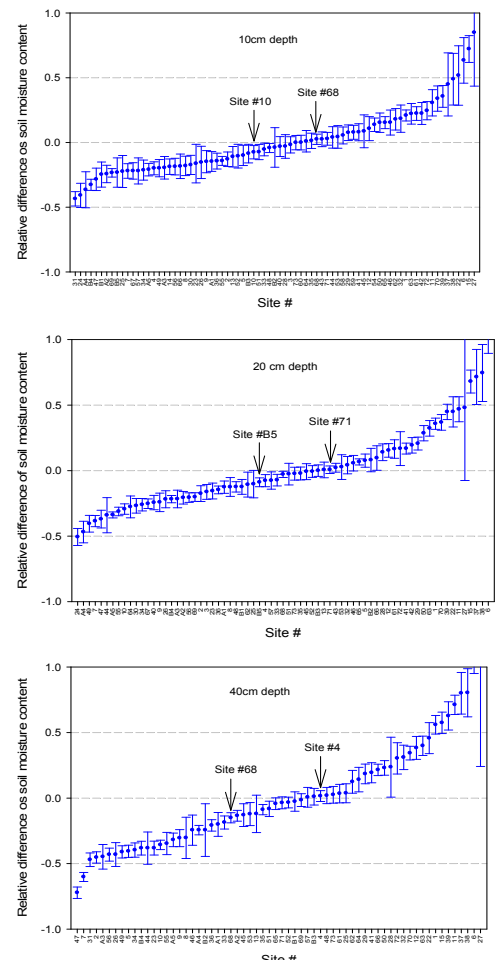

Site \#
HESSD

4, 1185-1214, 2007

Temporal stability of soil moisture spatial variability

X. Zhou et al.

Title Page

Abstract

Introduction

Conclusions

References

Tables

Figures

14

4

Back

Close

\section{Full Screen / Esc}

Printer-friendly Version

Interactive Discussion 


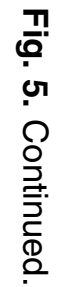

$\overrightarrow{0}$

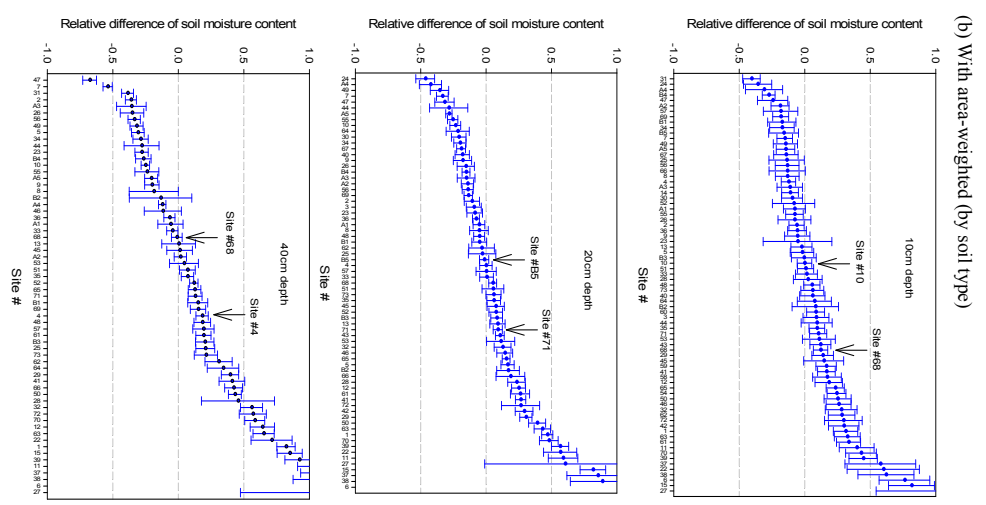

署 


\section{HESSD}

$4,1185-1214,2007$

(a) Soil moisture content at 20- and 80-cm depths
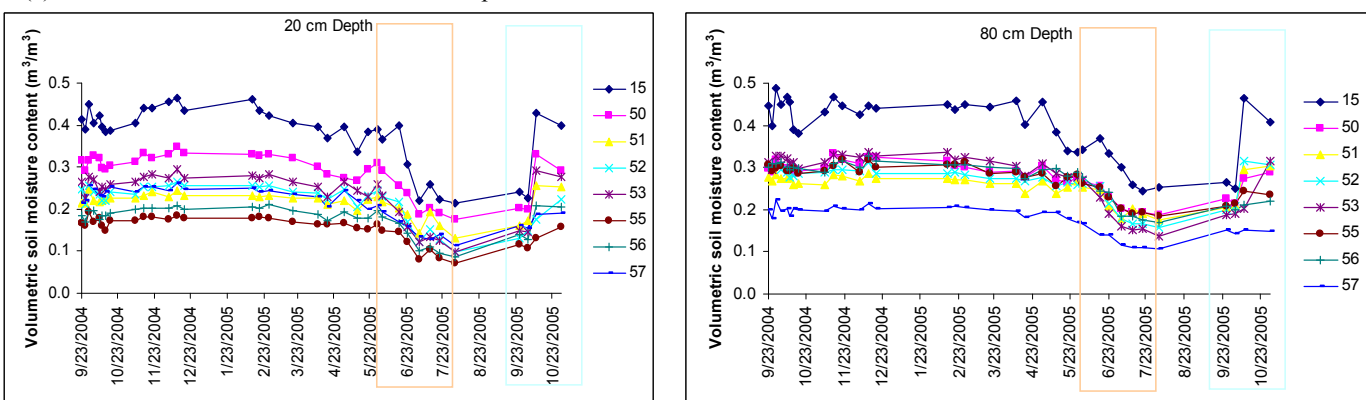

(b) Relative difference of soil moisture content at 20- and 80-cm depths
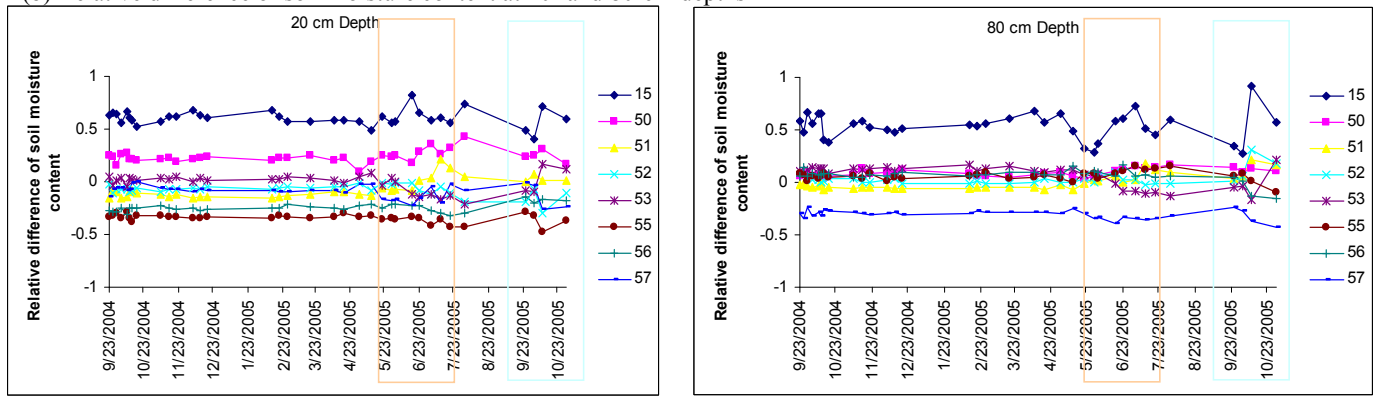

Fig. 6. (a) Volumetric soil moisture content and (b) relative difference of soil moisture content at $20-$ and $80-\mathrm{cm}$ depths of the monitored sites within the swale 3 . Red and blue windows represent the drying and recharging periods, respectively.

Temporal stability of soil moisture spatial variability

X. Zhou et al.

Title Page

Abstract

Introduction

Conclusions

References

Tables

Figures

14

4

Back

Close

Full Screen / Esc

Printer-friendly Version

Interactive Discussion

EGU 


\section{HESSD}

4, 1185-1214, 2007

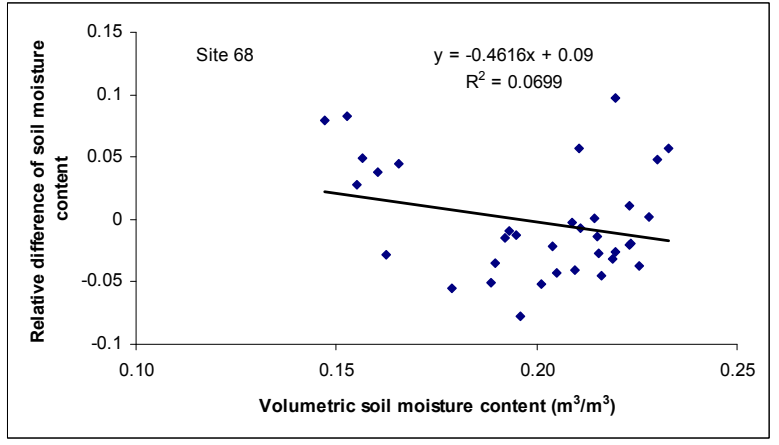

(b) Site 27

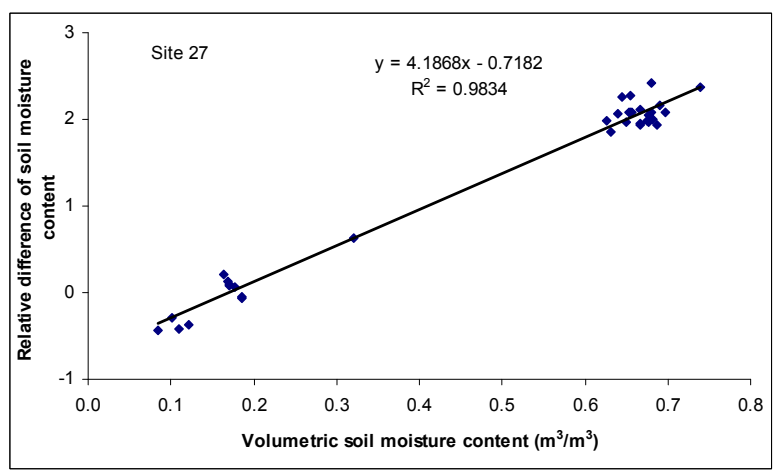

Fig. 7. Relative difference of soil moisture content versus soil moisture content at $40-\mathrm{cm}$ depth for (a) the time-stable site 68 and (b) the time-unstable site 27.

\section{Temporal stability of soil moisture spatial variability \\ X. Zhou et al. \\ Title Page

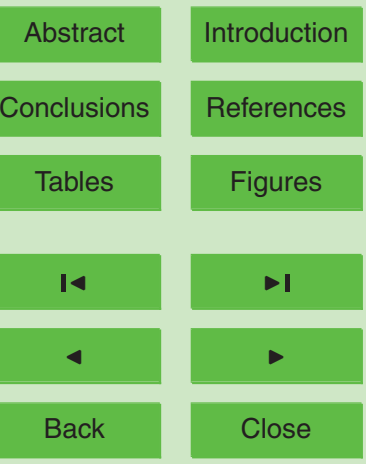 \\ Full Screen / Esc}

Printer-friendly Version

Interactive Discussion 


\section{HESSD}

4, 1185-1214, 2007

(a) $10 \mathrm{~cm}$ depth

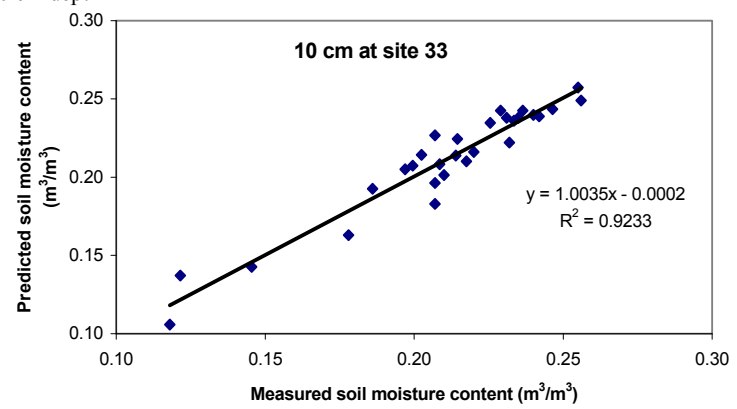

\section{Temporal stability of} soil moisture spatial variability

X. Zhou et al.

Title Page

(b) $20 \mathrm{~cm}$ depth

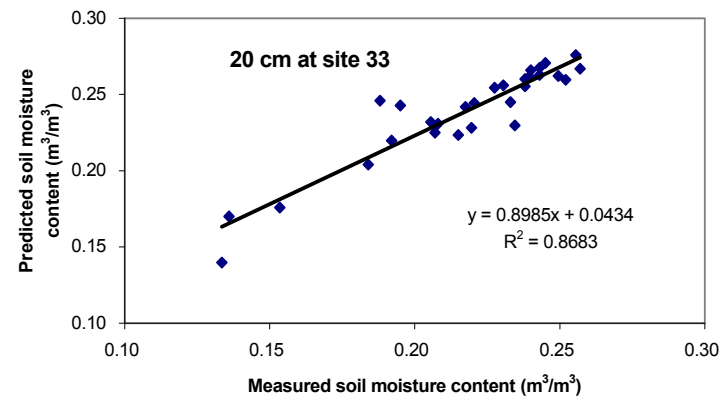

Introduction

Abstract

References

Conclusions

Figures

Tables
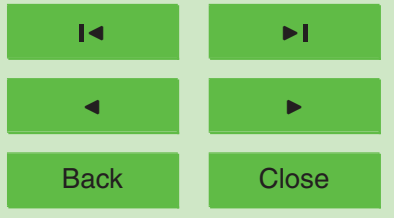

Back

Close

Full Screen / Esc

Fig. 8. The soil moisture content estimated from the time-stable site 68 versus the measured soil moisture content for the stable site 33 at (a) 10-, (b) 20- and (c)40-cm depths.

Printer-friendly Version

Interactive Discussion 


\section{HESSD}

4, 1185-1214, 2007

\section{Temporal stability of} soil moisture spatial variability

(c) $40 \mathrm{~cm}$ depth

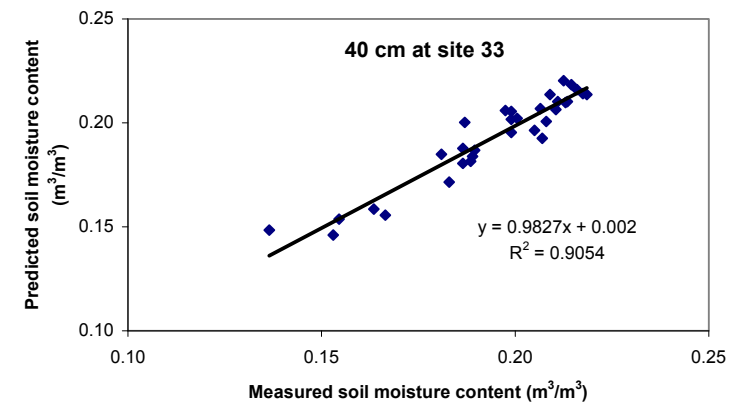

X. Zhou et al.

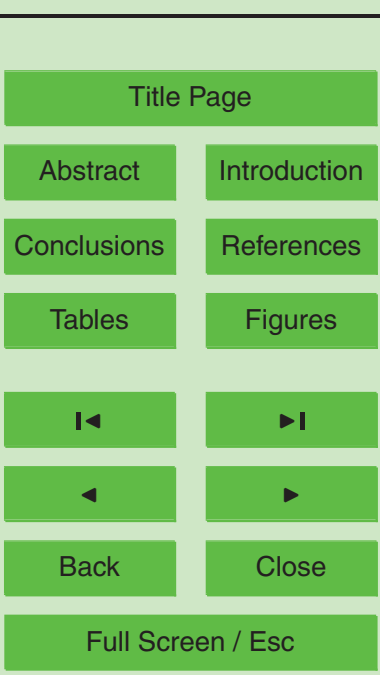

Printer-friendly Version

Interactive Discussion 


\section{HESSD}

(a) $10 \mathrm{~cm}$ depth

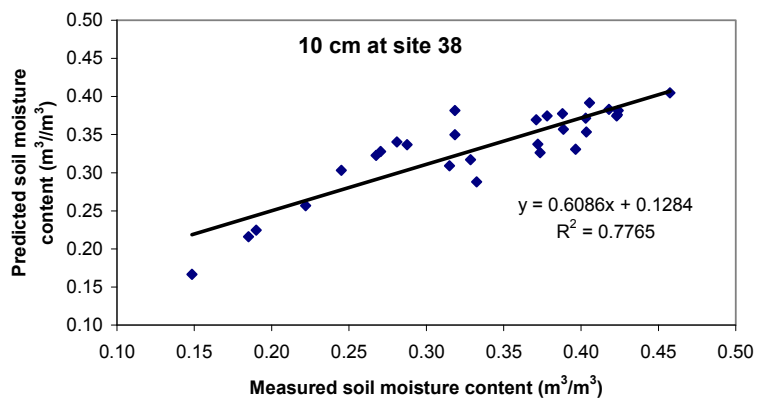

(b) $20 \mathrm{~cm}$ depth

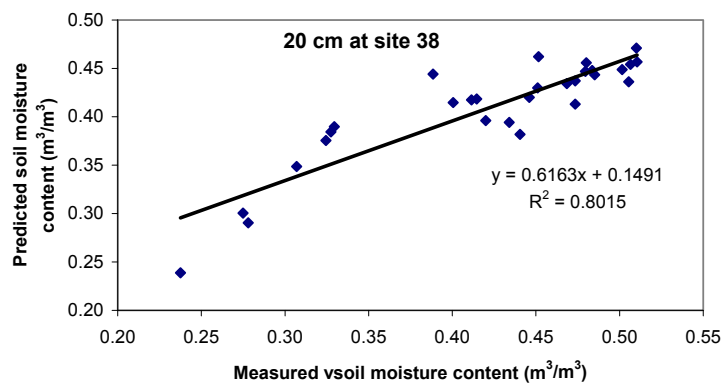

Fig. 9. The soil moisture content estimated from the time-stable site 68 versus the measured soil moisture content for the less stable site 38 at (a) 10-, (b) 20- and (c) 40-cm depths.
4, 1185-1214, 2007

\section{Temporal stability of} soil moisture spatial variability

X. Zhou et al.

Title Page

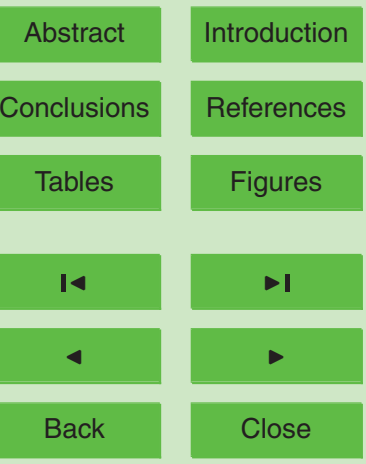

Full Screen / Esc

Printer-friendly Version

Interactive Discussion 


\section{HESSD}

4, 1185-1214, 2007

\section{Temporal stability of} soil moisture spatial variability

Fig. 9. Continued.

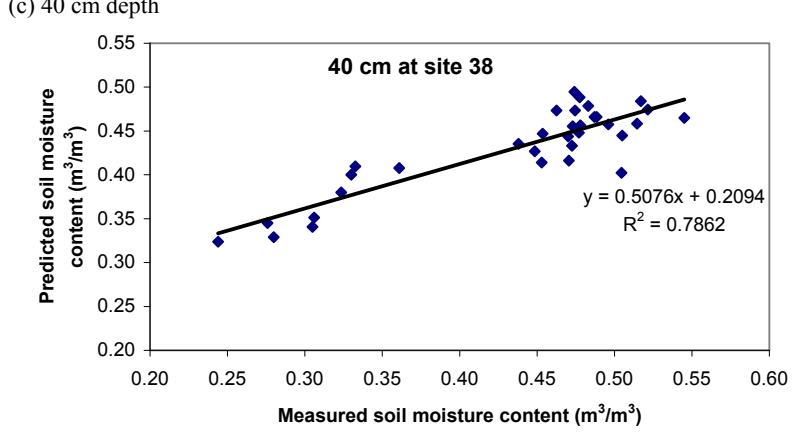

X. Zhou et al.

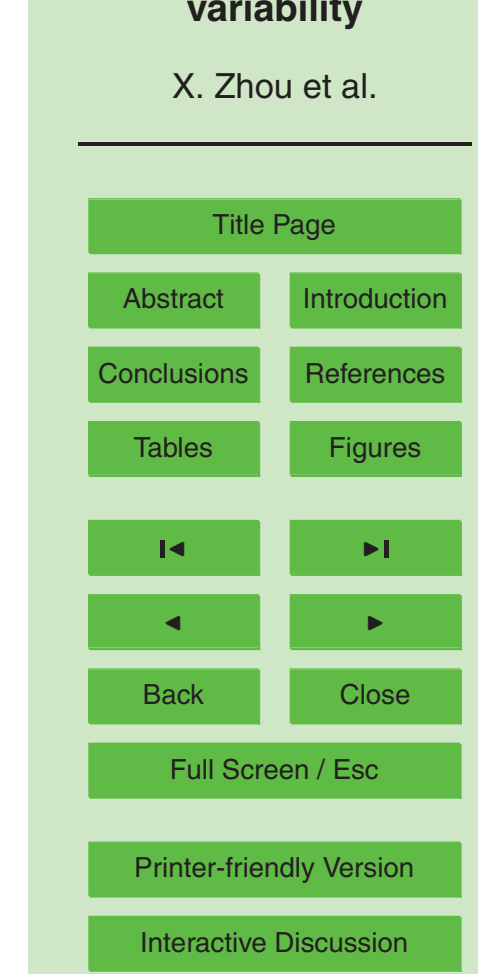

EGU 